\title{
Dampak Pariwisata Bahari Terhadap Ekosistem Terumbu Karang di Perairan Nusa Penida, Bali
}

\author{
[The Impact of Tourism on Marine Ecosystems Against The Coral Reefs in The \\ Waters of Nusa Penida, Bali]
}

lis Jubaedah, Pigoselpi Anas

Jurusan Penyuluhan Perikanan, Sekolah Tinggi Perikanan

Jalan Cikaret No. 2, Bogor Selatan, Kota Bogor 16132

Diterima : 28 Januari 2019; Disetujui : 14 Maret 2019

\begin{abstract}
Abstrak
Wilayah Perairan Nusa Penida memiliki luas 20.057 ha dengan tingkat keanekaragaman hayati pesisir dan laut yang tinggi serta merupakan sumber mata pencaharian masyarakat setempat terutama dari perikanan dan pariwisata bahari. Terumbu karang merupakan salah satu ekosistem yang cukup potensial serta memiliki keindahan alam yang unik sehingga menarik perhatian wisatawan untuk berkunjung. Namun sekarang menghadapi beberapa ancaman yang cukup serius. Selain kerusakan alami, kerusakan ekosistem terumbu karang juga disebabkan akibat adanya aktivitas manusia. Pengambilan data telah dilakukan pada bulan November 2017. Penelitian bertujuan untuk mengkaji dampak pariwisata bahari terhadap keberadaan ekosistem terumbu karang: menganalisis luasan tutupan terumbu karang, kelimpahan dan biomas ikan. Metode penelitian observasi lapangan dilanjutkan wawancara dengan responden melalui Focus Group Discussion. Data lain yang dikumpulkan diperoleh dengan studi pustaka, dan dari Unit Pelaksana Teknis (UPT) kawasan konservasi, Balai Pengelolaan Sumberdaya Pesisi dan Laut (BPSPL). Pariwisata bahari di Kawasan Konservasi Perairan Nusa Penida berdampak pada penurunan luasan tutupan karang keras sebesar 4,0\%. Demikian juga persentase penutupan karang hidup relatif mengalami penurunan sebesar 2,7\%. Namun kepadatan rata-rata ikan karang per hektar mengalami peningkatan dari 1253,6 menjadi 2813,7 individu. ha-1 ${ }^{-1}$ demikian juga biomasnya rata-rata mengalami peningkatan dari $347,2 \mathrm{~kg}$.ha- ${ }^{-1}$ menjadi $468,1 \mathrm{~kg}$. ha-1 .
\end{abstract}

Kata kunci : kerusakan lingkungan; Nusa Penida; ponton; tutupan karang

\section{Abstract}

The water area of Nusa Penida has an area of 20,057 ha with high levels of coastal and marine biodiversity and is the source of livelihood of local people, especially from fisheries and maritime tourism. Coral reefs are one of the most potential ecosystems and have unique natural beauty that attracts tourists to visit. But now face some serious threats. In addition to natural damage, coral reef ecosystem damage is also caused by human activity. Data retrieval was conducted in November 2017. Research aims to assess the impact of maritime tourism on the existence of coral reef ecosystem: analyzing the area of coral cover, abundance and biomass of fish. The field observation research method continued to interview with respondents through the Focus Group Discussion. Other Data collected is obtained by the study of the library, and from the technical Implementation Unit (UPT) of Conservation Area, the Commissioner of Resource Management and Sea (BPSPL). Maritime tourism in the water conservation area of Nusa Penida affects the decrease in hard coral cover of $4,0 \%$. Similarly, the closing percentage of live corals has decreased by $2,7 \%$. However, the average density of coral fishes per hectare has increased from $1253,-.6$ to $2813,-.7$ individuals. ha- ${ }^{-1}$, so the average biomass has increased from $347,2 \mathrm{~kg}$. ha-1 to $468.1 \mathrm{~kg} \cdot \mathrm{ha}^{-1}$.

Keywords: coral cover; environmental damage; Nusa Penida; pontoon 
Penulis Korespondensi

lis Jubaedah | lisjubaedah.stp@gmail.com

\section{PENDAHULUAN}

Perairan Nusa Penida merupakan daerah perlindungan laut di Kabupaten Klungkung, Provinsi Bali. Perairan ini memiliki pasir putih dan terumbu karang yang indah. Kekayaan dan keindahan laut, serta letaknya yang strategis serta mudah dicapai, menyebabkan berkembangnya pariwisata bahari di Nusa Penida (Pemerintah Daerah Klungkung 2010).

Terumbu karang tersebar luas di perairan tropis wilayah pesisir dan laut yang memiliki produktivitas dan keanekaragaman hayati yang tinggi serta memiliki nilai estetika yang tinggi, namun mudah terdegradasi jika kualitas lingkungan berubah, sehingga ekosistem ini menempati posisi penting dalam peta keanekaragaman hayati dan merupakan tujuan wisata nasional maupun internasional. Nusa Penida merupakan kawasan konservasi perairan (KKP) karena merupakan tempat pemijahan dan pembesaran berbagai macam biota laut dan banyak memiliki keindahan ekosistem yang unik seperti ekosistem terumbu karang Kawasan konservasi perairan Nusa Penida memiliki tujuh wilayah yaitu wilayah untuk pendidikan dan penelitian, perikanan berkelanjutan, pariwisata bahari, wisata bahari khusus, budidaya rumput laut, suci pura, dan pelabuhan (BPS 2012). Kawasan konservasi ini dapat dimanfaatkan secara berkelanjutan untuk mendukung pengembangan ekonomi masyarakat lokal. Selain itu terbentuknya kawasan konservasi sebagai upaya untuk meningkatkan kesejahteraan masyarakat sekitar. Daerah Pariwisata Bahari memiliki luas sekitar 1,221.28 hektar yang ada didalam KKP Nusa Penida.

Zona wisata bahari diharapkan dapat memperluas lapangan pekerjaan, kesempatan berusaha, meningkatkan pendapatan daerah dan devisa negara. Pengembangan wisata bahari juga diharapkan dapat mempertahankan dan memelihara keberlanjutan ekosistem pesisir dan laut serta memelihara kelestarian budaya dan adat istiadat masyarakat.

Kegiatan wisata bahari di Nusa Penida mulai berkembang pada tahun 1990. Sarana dan prasarana dibangun dengan berbagai ragam aktivitas wisata bahari yang semakin menarik perhatian pengunjung. Penunjang aktivitas wisata salah satunya adalah telah dibangun konstruksi apung berupa ponton. Jumlah ponton awalnya hanya ada 2 (dua) unit, kemudian meningkat menjadi 7 (tujuh) unit pada tahun 2015 dan pada tahun 
2017 jumlah ponton sudah mencapai 24 unit (komunikasi pribadi, 2017). Di Kawasan perairan Nusa Penida terdapat 20 titik lokasi penyelaman dan memiliki 3 (tiga) Cruises besar yang masing-masing memiliki ponton yang rata-rata dapat membawa turis sekitar 500-1000 orang.hari-1. Diperkirakan sekitar 250 ribu turis datang berkunjung ke Nusa Penida setiap tahunnya. Kunjungan wisatawan yang terbanyak (peak-season) adalah bulan AgustusSeptember, sedangkan low season pada bulan Januari-Februari.

Kawasan konservasi perairan di Nusa Penida memiliki keindahan dengan pasirnya yang putih dan keanekaragaman hayati yang tinggi. Sekarang ekosistem tersebut menghadapi ancaman selain karena faktor alami juga akibat dari berbagai aktivitas manusia yang menyebabkan perubahan pada ekosistem, rusaknya terumbu karang serta terjadi penurunan luas tutupan karang. Pemanfaatan kawasan konservasi sebagai wisata bahari perlu memperhatikan dampaknya terhadap keberlanjutan kawasan konservasi. Penelitian bertujuan untuk mengkaji dampak pariwisata bahari terhadap ekosistem terumbu karang yang produktif dan keanekaragaman yang tinggi serta menjadi tempat mencari nafkah penduduk sekitar. Hasil kajian ini merupakan salah satu bahan rujukan dalam menyusun dan merancang serta mengambil kebijakan dalam mengelola kawasan konservasi perairan sebagai kawasan pariwisata bahari yang berkelanjutan.

\section{BAHAN DAN METODE PENELITIAN}

Penelitian ini bersifat deskriptif eksploratif dan desk study dari beberapa hasil penelitian yang sudah ada serta pengamatan langsung di lapangan di wilayah konservasi perairan Nusa Penida Bali. Pengambilan data dilakukan dengan metode survei melalui observasi di lapangan, wawancara dan FGD dengan kepala Unit Pelaksana Teknis (UPT) kawasan konservasi, kepala Balai Pengelolaan Sumberdaya Pesisi dan Laut (BPSPL), Coral Triangle Center (CTC) dan LMA (Asosiasi Pengelola Nusa lembongan/ KPL (Kelompok Penyelam Lembongan). Bahan penelitian yang dipergunakan berupa kuisioner. Data sekunder diperoleh melalui studi pustaka dari beberapa laporan hasil kajian maupun penelitian yang sudah ada dan instansi terkait.

\section{HASIL DAN PEMBAHASAN}

\section{Ekosistem Terumbu Karang di} Perairan Nusa Penida

Luas ekosistem terumbu karang di periaran Nusa Penida sekitar 1.419 hektar. Perairan ini memiliki tipe terumbu karang tepi (fringing reef) yang mengelilingi Nusa Penida (CTC 2011). 
Perairan Nusa Penida memiliki sekitar 296 jenis karang. Persentase karang hidup berkisar antara 70\%-75\% yang terdiri dari karang lunak hidup rata-rata $29,8 \%$ dan karang keras hidup rata-rata 40.3\%. Untuk masing-masing kedalaman adalah karang keras di kedalaman 3 meter adalah $42.9 \%$ dan di kedalaman 10 meter adalah 38,2\%. Persentase karang lunak di kedalaman $3 \mathrm{~m}$ adalah $31,5 \%$ dan di kedalaman 10 meter adalah 28,-.4\% (CTC 2011). Terlihat persentase karang keras maupun karang lunak menurun seiring dengan bertambahnya kedalaman. Hal tersebut dimungkinkan karena semakin dalam perairan suhu perairan semakin dingin Nybakken (1997) mengatakan, kedalaman perairan membatasi perkembangan terumbu karang, selain itu faktor fisika-kimia yang mempengaruhi pertumbuhan adalah suhu, salinitas dan jenis substrat. Terumbu karang juga merupakan habitat
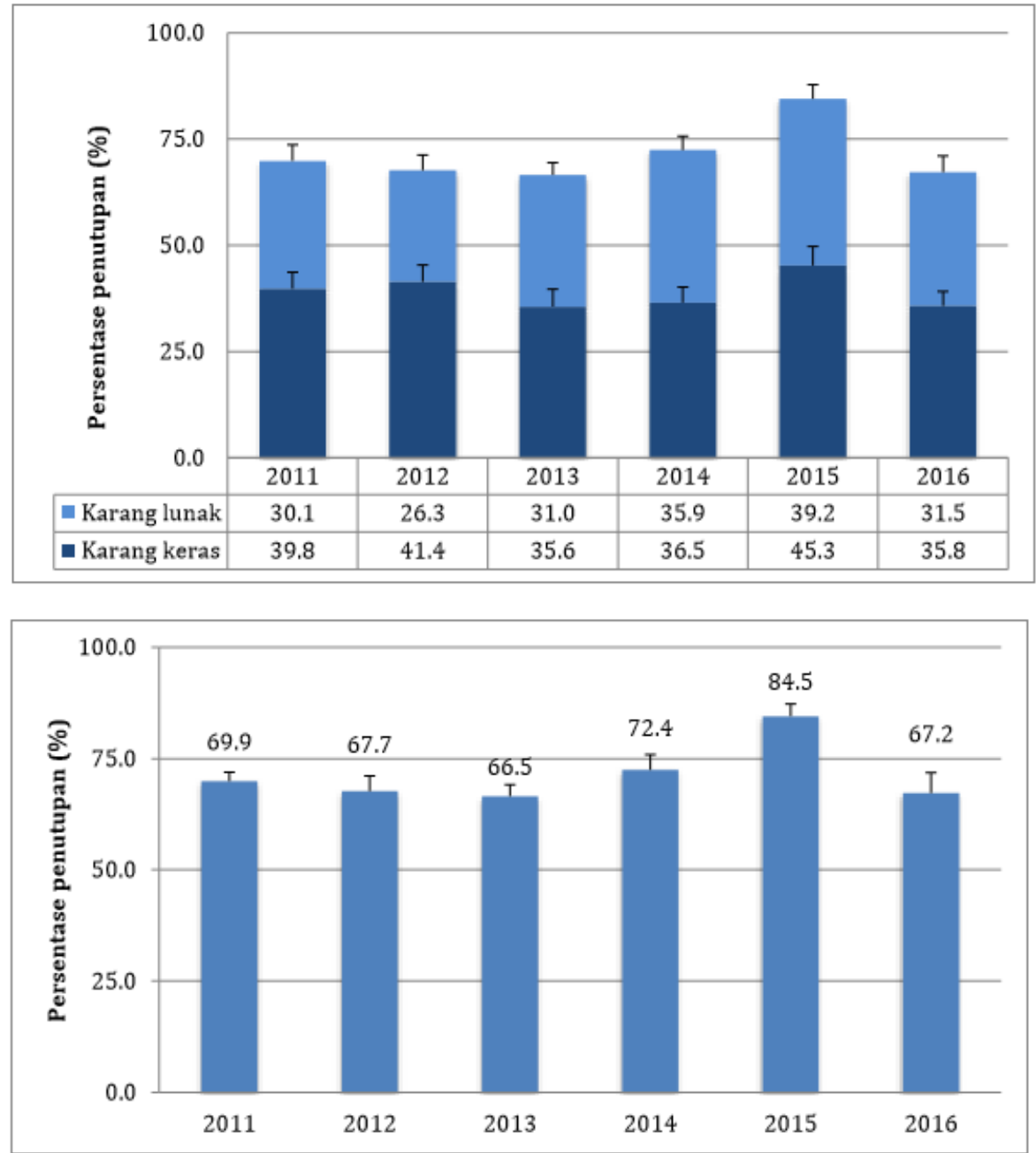

Gambar 1. Persentase Penutupan Karang Hidup di KKP Nusa Penida Sumber/Source: CTC, 2017) 
penting berbagai biota perairan, diantaranya yaitu ikan karang, ikan pelagis dan ikan demersal.

Dinamika ekosistem terumbu karang mulai tahun 2011 sampai dengan 2016, dilihat dari persentase luasan tutupan karang menunjukkan adanya kecenderungan penurunan luasan tutupan karang keras sebesar 4,0\%. Demikian juga persentase penutupan karang hidup relatif mengalami penurunan sebesar 2,7\%. Namun demikian kondisi kesehatan karang masih dalam kategori baik. Penurunan luasan tutupan karang ini diduga selain karena faktor alam yaitu perubahan iklim yang mengakibatkan perubahan suhu yang berdampak pada adanya pemutihan karang (bleaching) dan faktor manusia yaitu berkembangnya sarana dan prasarana wisata bahari berupa ponton yang penempatannya berada tepat diatas terumbu karang sehingga penetrasi cahaya matahari terganggu. Persentase penutupan karang hidup di KKP Nusa Penida dapat terlihat pada Gambar 1.

Berdasarkan hasil penelitian yang telah dilakukan oleh Bato, Yulianda, dan Fahruddin (2013) menyebutkan ekosistem terumbu karang di perairan Nusa Penida pada tahun 2010-2012 dikategorikan baik sampai dengan kondisi sangat baik, jenis karang yang dominan ditemukan adalah Acropora.
Organisme hidup lainnya yang ditemukan di terumbu karang yaitu anemone, algae, tridacna crinoid, dan linkia. Luasan tutupan komunitas karang berkisar antara 52\% - 97\%. Demikian juga tingkat kesehatan karangnya yang masih sangat baik serta kelimpahan ikan karangnya yang masih tinggi. Langga (2010) menjelaskan kelimpahan individu ikan dipengaruhi oleh kondisi luasan tutupan karang hidup. Semakin luas tutupan karang yang hidup, maka kelimpahan ikan juga tinggi. Allen dan Erdmann (2009) melaporkan di kawasan perairan Nusa Penida terdapat 576 jenis ikan. Keanekaragaman dan kelimpahan ikannya sangat tinggi sehingga hal tersebut juga menjadi daya tarik wisatawan untuk berkunjung ke kawasan Nusa Penida untuk melakukan aktivitas wisata bahari.

Kondisi ekosistem terumbu karang yang baik diikuti juga dengan melimpahnya ikan karang di KKP Nusa Penida. Hasil pemantauan yang dilakukan oleh LSM (CTC) selama 5 (lima) tahun mulai dari tahun 2011-2016 memperlihatkan kepadatan rata-rata ikan karang per hektar mengalami peningkatan dari 1253,6 menjadi 2813,7 individu.ha ${ }^{-1}$, demikian biomasnya ratarata mengalami peningkatan dari 347,2 kg.ha- ${ }^{-1}$ menjadi 468,1 kg.ha- ${ }^{1}$ (Gambar 2). 

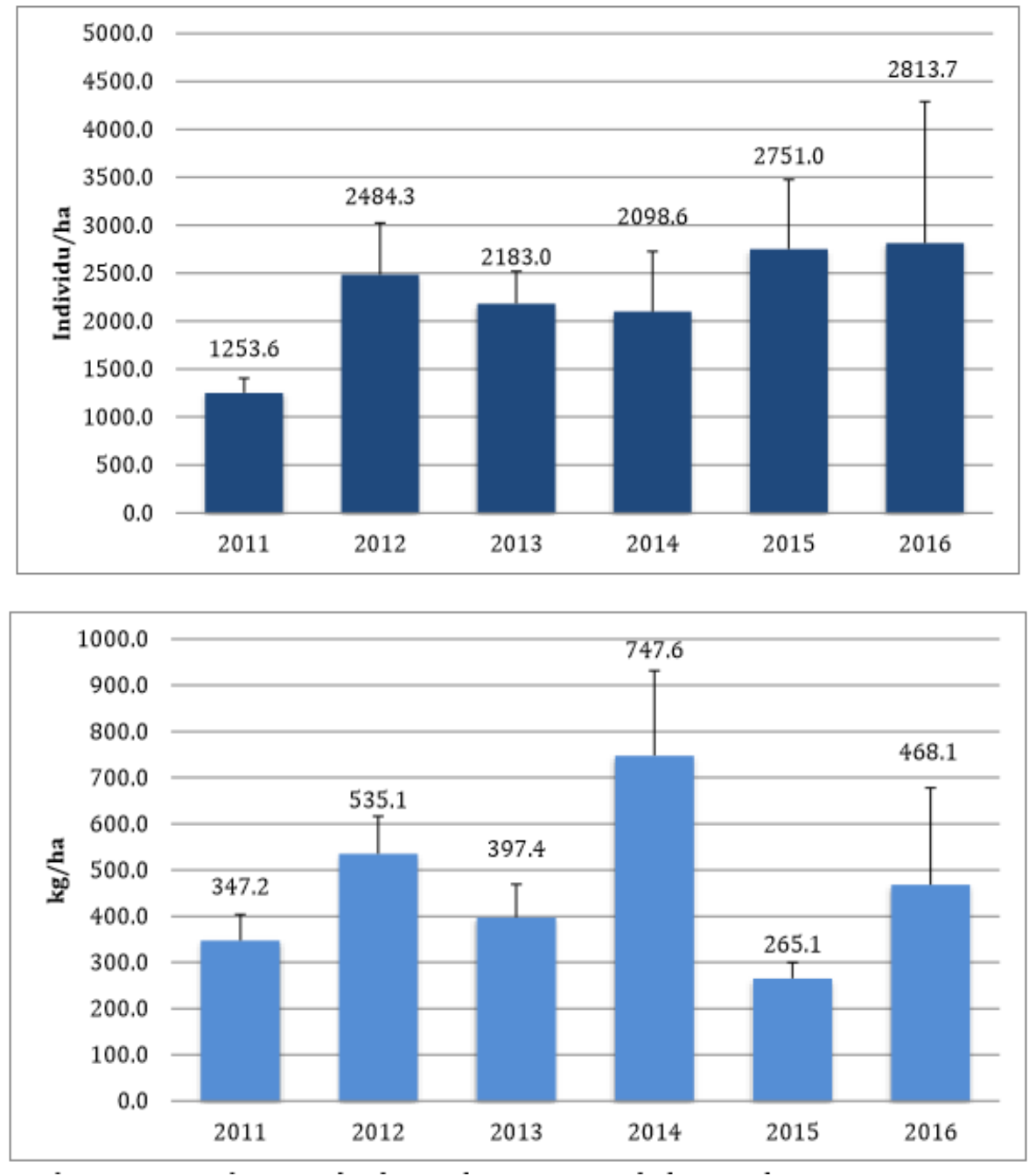

Gambar 2. Kepadatan dan biomas rata-rata individu ikan karang di KKP Nusa Penida Sumber/Source: (CTC, 2017)

Luasan tutupan terumbu karang yang menurun di Nusa Penida tidak selalu diikuti dengan menurunnya jumlah dan biomas ikan yang ada di ekosistem terumbu karang. Hal ini dikarenakan pertumbuhan dan kelimpahan ikan sangat dipengaruhi oleh faktor internal yaitu jenis ikan, umur dan faktor eksternal yaitu kualitas lingkungan perairan (Effendie 1997). Namun sebaliknya hasil penelitian yang dilakukan oleh Carpeter (1981) dalam
Russ (1991) menyatakan bahwa jika luas penutupan terumbu karang hidup tinggi, maka keanekaragaman dan kelimpahan ikan, serta biomassa ikannya juga meningkat. Selanjutnya Marsaoli (1998) menyatakan adanya respon linier positif yang jauh berbeda antara luas penutupan karang hidup dan kelimpahan ikan karang. Semakin tinggi luas penutupan karang hidup, maka semakin tinggi pula kelimpahan ikan karang. Hal ini berbeda dengan hasil pengamatan 
yang telah dilakukan LSM CTC pada 2017. Namun demikian kondisi karang yang baik signifikan dengan jumlah dan biomas ikan yang tinggi.

\section{Pariwisata Bahari Berkelanjutan di Perairan Nusa Penida}

Pariwisata bahari (marine tourism) merupakan wisata yang menyangkut kelautan. Perairan Nusa Penida merupakan kawasan konservasi yang berbasis ekowisata berkelanjutan. Pariwisata yang berkelanjutan artinya aktivitas pariwisata yang tidak merusak dan bertanggungjawab dalam melestarikan lingkungan laut. Beberapa aktivitas diperairan pantai yang sering dilakukan oleh wisatawan diantaranya adalah berenang, snorkeling, dan diving. Berdasarkan hasil penelitian yang telah dilakukan Bato et al. (2013), mengatakan bahwa wisata bahari yang mungkin bisa dilakukan adalah penyelamam, snorkeling dan wisata pantai. Kesesuaian kawasan konservasi sebagai kawasan wisata penyelaman, snorkeling berada di Desa Jungut Batu (mangrove point), Desa Toyapakeh, Desa Ped, dan Desa Sakti. Pemanfaatan lokasi pariwisata perlu disesuaikan dengan potensi yang dimiliki masingmasing wilayah, sehingga dalam pengelolaannya lebih optimal dan berkelanjutan. Pernyataan tersebut didukung oleh Collins (2008) yang mengatakan bahwa pemanfaatan lokasi pariwisata dapat disesuaikan dengan kondisi atau potensi yang dimilikinya. Lokasi snorkeling di Desa Jungut Batu menjadi lokasi yang sering dikunjungi oleh wisatawan baik dalam negeri maupun luar negeri, karena selain memiliki 109 jenis ikan karang dan kecerahan perairan $100 \%$.

Pariwisata bahari berkelanjutan di Kawasan Konservasi Perairan (KKP) merupakan upaya pemerintah setempat untuk melestarikan potensi sumber daya alam, meningkatkan kesejahteraan masyarakat dan menjadi sumber pendapatan yang berkesinambungan. Apabila pengembangan ekowisata menggunakan pendekatan partisipatif, kesejahteraan masyarakat akan dapat ditingkatkan dan lingkungan dapat dipertahankan kualitasnya (Fandeli 2002). Mohan dan Stokke (2000) mengatakan ekowisata merupakan salah satu bentuk pembangunan yang bersifat partisifatif terutama dari masyarakat lokal, akan tetapi keberhasilan partisipasi tergantung pada tujuan dan ideologi dari masing-masing stakeholder. Tujuan untuk mengembangkan ekowisata yaitu untuk mensejahterakan masyarakat, menciptakan adanya lapangan kerja dan lapangan berusaha untuk masyarakat di sekitar kawasan konservasi, kesadaran masyarakat terhadap kelestarian sumberdaya alam hayati meningkat, mengembangkan manfaat pariwisata, 
sehingga dapat memberikan kontribusi terhadap pendapatan atau pemasukan dana bagi kepentingan pemerintah dan pengelola.

Terdapat salah satu ikan purba di Kawasan Konservasi Nusa Penida yang masih hidup yaitu ikan Mola mola (sunfish). Ikan mola-mola menjadi icon wisata karna mempunyai daya tarik tersendiri dari bentuk tubuhnya yang besar dan gerakannya yang lemah gemulai sehingga disukai oleh penyelam-penyelam dari manca negara. Oleh karena itu Kawasan ini menjadi magnet wisata baru terutama karena keanekaragaman hayati lautnya. Status pengelolaan kawasan yang selalu berubah-ubah, akibat perubahan kewenangan KKP Nusa penida pasca diberlakukannya Undang-Undang No 23 tahun 2014 tentang pemerintah daerah, pengelolaan wilayah pesisir berubah dari kabupaten kembali ke provinsi. Hal ini membuat pengelolaan kawasan belum dimanfaatkan secara optimal. Berdasarkan hasil survei di Nusa Penida, selain wisata penyelaman, terdapat lokasi yang memiliki tempat rekreasi yang indah yaitu Desa Sakti. Wisata untuk rekreasi pantai di Desa Sakti sangat cocok karena memiliki kedalaman perairan yang dangkal, pantai pasirnya putih, sehingga dasar perairan bisa terlihat dengan jelas. Pengembangan pariwisata bahari di KKP sangat perlu memperhatikan kemampuan kawasan untuk dijadikan sebagai kawasan wisata yang berkelanjutan. Hal ini dilakukan untuk mengurangi tekanan akibat dari aktivitas pengunjung di kawasan wisata. Schleyer dan Tomalin (2000); Zakai dan Chadwick-Furman (2002), menjelaskan salah satu upaya dalam mengurangi tekanan dari aktivitas yang dapat merusak ekosistem terumbu karang adalah dengan cara membatasi jumlah dan waktu wisata pantai.

\section{Dampak Pariwisata Bahari Terhadap Terumbu Karang}

Salah satu tujuan pariwisata penyelaman dengan kondisi ekosistem terumbu karang yang paling baik terdapat di perairan kawasan konservasi Nusa Penida. Selain memiliki keindahan alam pantai yang indah dengan pasir putihnya, kecerahan perairannya baik juga keanekaragam jenis ikan dan karangnya yang tinggi. $\mathrm{Hal}$ ini mendorong wisatawan baik lokal maupun manca negara untuk berkunjung ke Nusa Penida. Dari hasil wawancara melalui kegiatan FGD jumlah pengunjung yang berwisata meningkat dari tahun ke tahunnya. Hal ini menunjukkan dengan adanya daerah wisata di kawasan konservasi perairan, mempunyai pengaruh terhadap peningkatan kunjungan wisatawan. Pengembangan pariwisata bahari mempunyai dampak positif dan negatif 
Tabel 1. Dampak pariwisata bahari terhadap ekosistem terumbu karang.

\begin{tabular}{|c|c|c|}
\hline $\begin{array}{l}\text { Faktor pariwisata bahari } \\
\text { (Marine Tourism factors) }\end{array}$ & $\begin{array}{l}\text { Dampak positif } \\
\text { (Positive Impact) }\end{array}$ & $\begin{array}{l}\text { Dampak negative } \\
\text { (Negative impact) }\end{array}$ \\
\hline Wisatawan & $\begin{array}{l}\text { Terbentuknya lapangan } \\
\text { kerja dan pendapatan }\end{array}$ & $\begin{array}{l}\text { Sampah yang dibuang } \\
\text { pengunjung meningkat, } \\
\text { adanya limbah cair dari } \\
\text { pembersih ponton, } \\
\text { kurangnya kesadaran akan } \\
\text { kelestarian lingkungan }\end{array}$ \\
\hline Kapasitas wisatawan & $\begin{array}{l}\text { Pengembangan ekonomi } \\
\text { masyarakat lokal }\end{array}$ & $\begin{array}{l}\text { Perubahan dan } \\
\text { peningkatan beban wilayah } \\
\text { KKP }\end{array}$ \\
\hline \multirow[t]{3}{*}{ Area penambatan ponton } & $\begin{array}{l}\text { Wisatawan dapat melihat } \\
\text { terumbu karang yang bagus } \\
\text { dan indah karena lokasinya } \\
\text { di zona inti }\end{array}$ & $\begin{array}{l}\text { Bergeser dan terseret arus } \\
\text { jangkar ponton dan alat } \\
\text { bantu wisata mematahkan } \\
\text { karang }\end{array}$ \\
\hline & & $\begin{array}{l}\text { Merusak habitat tempat } \\
\text { pemijahan, pembesaran } \\
\text { dan mencari makan. }\end{array}$ \\
\hline & & $\begin{array}{l}\text { Luas penutupan karang dan } \\
\text { populasi ikan menurun. }\end{array}$ \\
\hline Perubahan fungsi zona & $\begin{array}{l}\text { Memperkaya pengetahuan } \\
\text { akan kekayaan ekosistem } \\
\text { terumbu karang }\end{array}$ & $\begin{array}{l}\text { Perubahan lingkungan fisik } \\
\text { dan kimia, rusaknya } \\
\text { ekosistem terumbu karang. }\end{array}$ \\
\hline
\end{tabular}

terhadap ekosistem terumbu karang di wilayah kawasan konservasi perairan (Tabel 1).

Ponton terapung merupakan salah satu sarana wisata yang berkembang di kawasan konservasi perairan. Jumlah ponton meningkat secara drastis, menyebabkan wisatawan yang berkunjungpun meningkat dari sekitar 200 orang.ponton ${ }^{-1}$ pada tahun 2015 dan pada tahun 2017 sekitar 4001000 orang.ponton $^{-1}$. Hal ini tentu akan menumbuhkan ekonomi masyarakat setempat selain mengandalkan hasil kegiatan budidaya, penangkapan ikan juga jasa- jasa pariwisata. Kebanyakan dari wisatawan manca negara ini ingin melihat terumbu karang dan keanekaragaman ikan, melalui snorkeling, diving, dan sea-walker, dengan keberadaan ponton memudahkan wisatawan melihat secara langsung terumbu karang karena ponton-ponton tersebut berada tepat diatas hamparan terumbu karang yang bagus yang berada pada zona inti.

Aktivitas manusia di KKP semakin meningkat berdampak terhadap berbagai komponen ekosistem pesisir di duga merupakan salah satu penyebab terjadinya degradasi kualitas lingkungan dan terancamnya keanekaragaman 
hayati. Demikian pula pembangunan yang tidak memperhatikan efek lingkungan, konflik penggunaan lahan, pencemaran oleh limbah, pemanfaatan sumberdaya hayati secara illegal, tumpang tindih peraturan dan wewenang, permasalahan ekonomi masyarakat lokal, serta berbagai masalah sosial ekonomi lain secara langsung maupun tidak langsung telah mengancam keberlangsungan fungsi ekosistem pesisir. Berkurangnya fungsi ekosistem dari berbagai ekosistem pesisir juga dapat mengancam kehidupan masyarakat dan berpotensi mengakibatkan kerugian ekonomi bagi masyarakat pesisir.

Berdasarkan hasil wawancara dengan Kepala UPT KKP Nusa Penida Bali kerusakan terumbu karang yang ada di mangrove point mencapai 1800 meter persegi. Kerusakan terjadi akibat keberadaan ponton terapung yang semakin banyak dan tidak terkendali. Luasan ponton bervariasi dari $10 \times 10$ meter persegi hingga ada yang mencapai $10 \times 40$ meter persegi. Ponton tersebut berada di lokasi zona inti yang merupakan zona perlindungan. Keberadaan ponton ini berada tepat diatas terumbu karang sehingga menutupi areal terumbu karang. Dean dan Kleine (2012) melaporkan bahwa terumbu karang merupakan salah satu daerah yang subur sehingga menjadi habitat bagi beranekaragam biota yang ada di perairan untuk mencari makan, pemijahan dan pembesaran. Biota perairan terbanyak ditemukan di daerah terumbu karang. Karang merupakan hewan hidup yang masuk dalam filum Invertebrata. Pertumbuhan karang dimulai dengan sebuah polip kecil, yang mempunyai ukuran polip bervariasi dan sebagian besar hidupnya secara berkoloni membentuk terumbu. Adanya simbiosis zooxantela dalam terumbu karang membuat karang tampak berwarna dan indah.

Ponton terapung berada tepat diatas areal terumbu karang pada zona inti hal ini diduga mempengaruhi ekosistem terumbu karang karena menghalangi penetrasi cahaya matahari yang masuk ke perairan, sampah yang menutupi karang, demikian pula dengan bergeraknya beton ponton karena terombang-ambing oleh arus laut, adanya sea walker bawah laut, menyebabkan patahnya coral. Jumlah ponton yang semakin banyak dengan ukuran yang semakin besar juga diikuti jumlah wisatawan yang berkunjung meningkat.

\section{Berdasarkan hasil wawancara satu} unit ponton dapat menampung 500 hingga 1000 wisatawan. Hal ini mengakibatkan lingkungan tercemar karena adanya sampah dan limbah dari bahan-bahan kimia pembersih ponton 
serta perilaku sebagian wisatawan yang kurang menyadari pentingnya kelestarian ekosistem, padahal terumbu karang sangat membutuhkan sinar matahari, suhu serta kualitas air yang sesuai dan suhu yang baik untuk kehidupannya. Dean dan Kleine (2012) menjelaskan terumbu karang akan tumbuh dengan baik bila perairan jernih, suhu yang hangat antara $18-30{ }^{\circ} \mathrm{C}$. Ekosistem terumbu karang merupakan lingkungan yang sangat produktif karena terumbu karang merupakan tempat hidup alga sehingga terumbu karang merupakan sumber makanan utama berbagai species ikan. Terumbu karang merupakan habitat penting yang dibutuhkan untuk menjaga kehidupan ribuan species laut di samping sebagai sumber makanan, sumber penghasilan dan keindahannya,. Terumbu karang sangat membutuhkan sinar matahari, serta suhu dan kualitas air yang sesuai untuk kehidupannya. Jika terjadi perubahan salah satu kondisi ini akan mengancam kesehatan terumbu karang dan merusaknya bila kondisi berubah secara drastis.

Kerusakan terumbu yang terjadi KKP Nusa Penida disebabkan oleh pemutihan karang. Pemutihan karang terjadi pada tahun 2015 di beberapa titik akibat perubahan iklim, juga oleh karena ulah wisatawan dengan aksi corat coret terumbu karang, adanya skuter berjalan diatas terumbu karang dan Jumlah ponton yang tidak terkendali. Kerusakan terumbu karang semakin parah akibat ponton-ponton kapal semakin besar dan penempatan ponton dilokasi yang mempunyai terumbu karang yang bagus. Ardarini (2002) menjelaskan luasan terumbu karang yang rusak di sekitar ponton di Toyapakeh adalah 2.9075 ha. Penutupan karang hidup berkisar antara 8,08\%-90,44\% dengan rata-rata $42.82 \%$ atau dalam kategori rusak. Penutupan karang mati berkisar antara 0,60\%-41,42\%, dengan rata-rata $16,76 \%$ penutupan patahan karang berkisar antara 1,54\% - 58,72\%, dengan rata-rata $17,68 \%$ dan indeks mortalitas berkisar antara 0,01-0,83, dengan rata-rata 0,31. Kerusakan terumbu karang yang tinggi terjadi di daerah wisata akibat kerusakan mekanik seperti terinjaknya karang dan gesekan dengan rantai penyangga ponton.

Ekosistem terumbu karang termasuk sumberdaya alam yang dapat pulih, namun demikian ekosistem tersebut mempunyaai daya dukung terbatas. Apabila daya dukungnya sudah terlampaui maka keseimbangan ekosistem akan sulit terjadi. Dahuri (2003) menjelaskan ingkat pemanfaatan sumberdaya alam yang dapat pulih (Renewable Resources) hendaknya tidak melebihi kemampuan pulih sumberdaya tersebut dalam kurun waktu 
tertentu. Kerusakan terumbu karang tidak hanya menurunkan produksi ikan, namun meniadakan kesempatan kita semua untuk menikmati keindahan laut. Jika terumbu karang rusak akan sulit untuk tumbuh kembali. Degradasi lingkungan akan terus terjadi jika pengembangan wisata dan eksploitasi daya Tarik dan aktivitas wisata mengabaikan aspek kelestarian lingkungan. Degradasi lingkungan ini akan menyebabkan kawasan wisata kehilangan daya tariknya.

Berdasarkan hasil wawancara, keberadaan ponton tersebut juga tidak memberikan kontribusi terhadap anggaran pendapatan daerah. Hal ini menambah maraknya keberadaan ponton. Para pengelola dinilai lalai dan abai terhadap dampak rusaknya ekosistem terumbu karang demi mengejar keuntungan semata termasuk lemahnya pengawasan instansi terkait karena ketidak jelasan status pengelolaan KKP. Kerusakan terumbu karang akibat bergesernya beton tambatan dan material sarana wisata terjadi di Mangrove Point. Ponton dari bahan beton dan besi tertarik arus dan dengan mudah mematahkan koral-koral. Dengan semakin banyaknya jumlah ponton di duga mengakibatkan terumbu karang tertutup oleh ponton-ponton tersebut sehingga menghalangi penetrasi cahaya matahari yang berakibat pada menurunnya kesehatan karang, rusaknya terumbu karang karena kurangnya sinar cahaya matahari yang sangat dibutuhkan untuk kelangsungan hidupnya. Selain adanya limbah cair hasil dari kegiatan pembersihan ponton, rusaknya terumbu karang juga akibat dari daya dukung wisatawan yang sudah terlampaui karena jumlah pengunjung yang berlebih serta ulah wisatawan yang mencorat coret terumbu karang. Pengembangan sarana wisata bahari yang menyediakan wahana skuter di bawah laut sangat rentan merusak biota di perairan nusa penida. Kurangnya Kesadaran para pelaku wisata menjaga alam yang menjadi daya tarik para wisatawan.

Kerusakan alam bawah laut tersebut sudah sejak lama. Lambatnya tidak lanjut pemerintah karena perubahan kewenangan pasca UndangUndang No 23 Tahun 2014 tentang pemerintah daerah, kewenangan pesisir berubah dari kabupaten kembali ke provinsi. UPT Kementerian Kelautan dan Perikanan belum ada di tingkat provinsi sehingga belum ada yang menangani permasalahan KKP. Pengawasan kurang karena ketidakpastian status kewenangan atas pengelolaan KKP, hingga saat ini sudah beberapa kali perubahan status. Kewenangan atas kawasan konservasi perairan Nusa Penida merupakan kewenangan dari 
pemerintah daerah Kabupaten Klungkung sebelum Undang-Undang No 23 Tahun 2014 terbit,. Namun setelah terbitnya undang-undang tersebut, kewenangan atas KKP Nusa Penida merupakan wewenang provinsi. Proses pengalihan status pengelolaan KKP ke provinsi sedang berjalan, Keputusan Presiden yang baru Nomor 6 Tahun 2017 tentang penetapan kawasan Nusa Penida sebagai pulau-pulau kecil terluar sudah terbit. Secara otomatis kewenangan pengelola KKP menjadi kewenangan pemerintah pusat. Pemerintah pusat lamban dalam merespon terhadap kerusakankerusakan yang terjadi di KKP, karena belum menguasai kondisi lapangan dan juga tidak mengenal budaya masyarakat setempat. tidak adanya dana operasional teknis, Pengawasan terumbu karang yang seharusnya secara rutin oleh UPT KKP Nusa Penida tidak bisa dilakukan karena tidak dianggarkan dengan alasan KKP Nusa Penida merupakan kewenangan provinsi, sehingga pelanggaran semakin marak. Terdapat beberapa zona yaitu zona inti, pariwisata, dan zona budidaya rumput laut di kawasan KKP. Kawasan suci dan zona inti yang paling banyak dilanggar karena pada zona inti terumbu karangnya bagus. Kerusakan terumbu karang terjadi di perairan Nusa lembongan, Kecamatan Nusa Penida yang merupakan kawasan wisata di duga kerusakan terumbu karang akibat aktivitas pariwisata yang tidak terkendali, salah satunya pemasangan ponton, skuter di bawah laut. Hasil pemantauan peneliti, keberadaan ponton itu juga banyak yang tidak dilengkapi dengan surat izin karena pengurusan izinnya juga tidak jelas sehingga belum ada solusinya sampai sekarang.

Daya dukung kawasan konservasi perairan Nusa Penida perlu dihitung secara pasti jika kawasan ini dijadikan sebagai kawasan wisata yang lestari, sebab dengan menghitung daya dukung suatu wilayah maka dapat diketahui berapa kapasitas pengunjung yang optimal wilayah tersebut. Schleyer dan Tomalin (2000); Zakai dan ChadwickFurman (2002) melaporkan untuk mengurangi dampak negatif dari aktivitas pariwisata di ekosistem terumbu karang salah satunya dengan cara membatasi jumlah dan waktu pengunjung. (Bato et al. 2013) kapasistas optimal untuk kegiatan penyelaman, snorkeling dan rekreasi pantai kurang dari 250 orang pengunjung.hari-1. Jumlah pengunjung ke kawasan konservasi perairan Nusa Penida sudah melewati daya dukung kawasan karena jumlah wisatawan yang berkunjung pada tahun 2017 sekitar 400-1000 orang.ponton ${ }^{-1}$ 


\section{Peraturan dan Rehabilitasi Terumbu Karang}

Peraturan terkait pengelolaan ekosistem terumbu karang telah diatur dalam hukum nasional maupun internasional diantaranya: Konvensi perserikatan bangsa-bangsa tentang hukum laut tahun 1982 (UNCLOS, 1982), Deklarasi kelautan Manado tahun 2009. Pemerintah Indonesia bersama 5 negara lain telah menginisiasi pencanangan Coral Triangle Inisiatif (CTI) untuk melindungi ekosistem perairan. Sedangkan dalam hukum nasional telah diatur dalam UU nomor 5 tahun 1990 tentang konservasi sumberdaya hayati dan ekosistemnya; UU Republik Indonesia nomor 45 tahun 2009 tentang perubahan atas UU Republik Indonesia nomor 31 tahun 2004; UU nomor 1 tahun 2014 tentang pengelolaan wilayah pesisir dan pulau-pulau kecil; Peraturan Pemerintah nomor 60 tahun 2007 tentang konservasi sumber daya ikan dan Keputusan Menteri KP nomor: Kep.38/Men/2004 tentang pedoman umum pengelolaan terumbu karang.

Kegiatan rehabilitasi ekosistem perairan telah dilakukan oleh UPT KKP Nusa Penida dan bekerja sama dengan berbagai kalangan seperti Coral Triangle Center (CTC), Lembongan Marine Ascociation (LMA), Komunitas Penyelam Lembongan (KPL). Kegiatan yang sudah dilakukan tersebut meliputi transplantasi karang sebagai upaya penumbuhan karang dan pematauan kesehatan karang yang dilakukan secara rutin. Selain itu juga dilakukan pembinaan dan rehabilitasi karang yang rusak serta pemindahkan ponton serta moratorium. Pencegahan jangka panjang perlu dilakukan dengan adanya regulasi tentang kapasitas wisatawan ke KKP Nusa Penida. Upaya-upaya lain yang sedang dilakukan oleh pemerintah daerah setempat dengan melibatkan beberapa pihak lain diantaranya Desa Adat, UPTD KKP Nusa Penida, Dinas Perijinan dan Penanaman Modal Bali, Dinas Ketahanan Pangan dan Perikanan Klungkung, Dinas Pariwisata Klungkung, Dinas Perijinan dan Penanaman Modal Klungkung. Pengaturan Zonasi Pariwisata terkait lokasi selam, snorkeling, tambat kapal, banana boat, dan lainnya. Pemasangan rambu suar, buoy, balast, dan papan himbauan tidak pasang jangkar. Sementara untuk aktivitas wisata alam perairan akan ada Surat Himbauan Moratorium kepada pemilik ponton pada September 2017. Lalu ditentukan koordinat ponton yang diperbolehkan dan relokasi dari Mangrove Point sampai minggu pertama November. Untuk penanganan kerusakan karang akan ada penegakan hukum terhadap pelanggaran perusakan karang yang masih terjadi setelah dilakukan pembinaan. Kemudian pengaturan lokasi ponton bergerak dan 
rehabilitasi ekosistem. Untuk ini perlu diidentifikasi lokasi dan luas area yang rusak serta penentuan metode atau teknologi rehabilitasi.

\section{SIMPULAN DAN SARAN}

\section{Simpulan}

Pengembangan pariwisata bahari menimbulkan dampak terhadap ekosistem perairan di Nusa Penida. Dimana adanya kecenderungan penurunan luasan tutupan karang keras sebesar 4,0\%. Demikian juga persentase penutupan karang hidup relatif mengalami penurunan sebesar $2,7 \%$.

Namun kepadatan rata-rata ikan karang per hektar mengalami peningkatan dari 1253,6 menjadi 2813,7 individu.ha-1, demikian biomasnya rata-rata mengalami peningkatan dari 347,2 kg.ha- ${ }^{-1}$ menjadi 468,1 kg.ha- ${ }^{1}$ Keberadaan ponton terapung diduga berdampak terhadap kesehatan karang dan luasan terumbu karang serta rusaknya terumbu karang di zona inti yang merupakan zona perlindungan, kerusakan yang terjadi lebih banyak diakibatkan oleh ulah pelaku wisata dan masih rendahnya kesadaran masyarakat akan pentingnya menjaga terumbu karang. Kurangnya koordinasi antara pusat, provinsi dan daerah sehingga Pemerintah lamban dalam merespon kerusakan-kerusakan yang terjadi di Kawasan Konservasi perairan karena ketidak jelasan atau sering berubah ubahnya status pengelolaannya.

\section{Saran}

Guna meminimalisisir dampak pariwisata terhadap keberlanjutan terumbu karang di kawasan perairan Nusa penida direkomendasikan hal-hal pengelolaan sebagai berikut:

1. Pengaturan jumlah dan ukuran ponton yang diperbolehkan sesuai dengan daya dukung lingkungan

2. Pengaturan lokasi penempatan ponton sehingga tidak mengganggu kesehatan karang

3. Adanya koordinasi yang jelas antara pusat, provinsi dan daerah tentang status pengelolaan kawasan

4. Meningkatkan kesadaran masyarakat dan wisatawan akan pentingnya menjaga kelestarian terumbu karang dengan membuat peraturan-peraturan untuk perlindungan kawasan.

5. Pengelolaan ekowisata bahari yang berkelanjutan perlu dilakukan secara efektif, Peraturan-peraturan yang telah dibuat perlu diterapkan diiringi penegakan hukum yang tegas dan tanpa pandang bulu, serta mengurangi kegiatan penangkapan ikan yang merusak.

6. Meningkatkan pengawasan terhadap peraturan-peraturan yang telah ditetapkan 
7. Monitoring, pengawasan dan pengendalian dilakukan secara rutin serta sosialisasi kepada pengelola wisata dan masyarakat mengenai pentingnya kelestarian ekosistem terumbu karang.

\section{DAFTAR PUSTAKA}

Allen, Gerald R. dan Mark V. Erdmann. 2009. "Reef fish of Nusa Penida, Indonesia. Final Report to Conservation International."

Ardarini, F. 2002. "Kajian Dampak Pengembangan Pariwisata terhadap Kondisi Ekosistem Terumbu Karang dan Sosial Ekonomi Masyarakat Pesisir di Nusa Penida Bali [Thesis]." Institut Pertanian Bogor.

Bato, Marjan, Fredinan Yulianda, dan Achmad Fahruddin. 2013. "Kajian manfaat kawasan konservasi perairan bagi pengembangan ekowisata bahari: Studi kasus di kawasan konservasi perairan Nusa Penida, Bali." DEPIK Jurnal IImuIlmu Perairan, Pesisir dan Perikanan 2(2).

BPS. 2012. "Nusa Penida dalam Angka." Collins, John H. 2008. "Marine tourism in the Kimberley region of Western Australia." Geographical Research 46(1):111-23.
CTC. 2011. "Laporan monitoring kesehatan karang di KKP Nusa Penida."

Dahuri, Rokhmin. 2003 Keanekaragaman Hayati Laut: Aset Pembangunan Berkelanjutan Indonesia. Jakarta (ID): Gramedia Pustaka Utama.

Dean, A. dan D. Kleine. 2012. "Terumbu Karang dan Perubahan Iklim." University of Queensland, Australia.

Effendie, M. I. 1997. Biologi Perikanan (Edisi Revisi). Yogyakarta (ID): Yayasan Pustaka Nusantara.

Fandeli, Chafid. 2002. Perencanaan Kepariwisataan Alam. Fakultas Kehutanan, Universitas Gajah Mada.

Langga, Adi Nexon Tomyan. 2010. "Kajian Sumberdaya Terumbu Karang untuk Pengembangan Ekowisata Bahari di Perairan Kecamatan Semau, Kabupaten Kupang, Provinsi Nusa Tenggara Timur." Jurnal Lanskap Indonesia $4(1)$.

Marsaoli, M. 1998. "Hubungan Persentase Penutupan Karang Hidup dengan Densitas Beberapa Jenis Ikan Karang di Perairan Kepulauan Karimunjawa, Jepara [Tesis]." Institut Pertanian Bogor. 
Mohan, Giles dan Kristian Stokke. 2000.

"Participatory development and empowerment: the dangers of localism." Third world quarterly 21(2):247-68.

Nybakken, J. W. 1997. Marine Biology. Jakarta (ID): Gramedia.

Pemerintah Daerah Klungkung. 2010.

"Profil Kawasan Konservasi

Perairan (KKP) Nusa Penida, Kabupaten Klungkung- Provinsi Bali."

Russ, Garry R. 1991. "Coral Reef Fisheries: Effects and Yields." Hal. 601-35 in The Ecology of Fishes on Coral Reefs. Elsevier.

Schleyer, Michael H. dan Bruce J. Tomalin. 2000. "Damage on South African coral reefs and an assessment of their sustainable diving capacity using a fisheries approach." Bulletin of Marine Science 67(3):1025-42.

Undang-Undang No 23. 2014. UndangUndang tentang Pemerintah Daerah. Indonesia.

Zakai, David dan Nanette E. ChadwickFurman. 2002. "Impacts of intensive recreational diving on reef corals at Eilat, northern Red Sea." Biological Conservation 105(2):179-87. 
